The Review of Finance and Banking

print ISSN 2067-2713, online ISSN 2067-3825

Volume 13, Issue 1, Year 2021

http://dx.doi.org/10.24818/rfb.21.13.01.05, Pages 79-91

\title{
CORPORATE GOVERNANCE FEATURES AMONG EUROPEAN UNION COUNTRIES - AN EXPLORATORY ANALYSIS
}

\author{
IUSTINA ALINA BOITAN AND EWA WANDA MARUSZEWSKA
}

\begin{abstract}
This study investigates European Union countries' differences and similarities referring to corporate governance treated as (1) an external tool to overcome the conflict of interest described by the agency theory, and as (2) a result of an institutional environment. We conduct a cluster analysis and uncover an increased cross-country heterogeneity. Our findings might be of interest to European capital market investors. Differentiating between low-level corporate governance countries and high-level corporate governance countries may also be of regulators' interests who should search for other means to improve country-level corporate governance practices.
\end{abstract}

\section{INTRODUCTION}

Corporate governance consists of a set of mechanisms used to build trust between parties who establish their private contractual relations on different markets: capital market, employment market as well as when engaging with suppliers, customers, and other stakeholders. Understanding how entities respond to the need of a sound legal, regulatory and institutional framework - that market participants can rely on - is important not only from the local but also from the international perspective (OECD, 2015). Although the occurrence of the keyword "corporate governance" is among the most often found (Linnenluecke et al., 2020) and the scale of corporate governance literature is of considerable size, no definite answers to this issue have been formulated yet. Researchers from different geographical regions investigate distinct country-level and firm-level factors in order to find a comprehensive list of determinants of corporate governance practices.

Thus, knowing the level of shareholders' rights, the protection of shareholders against managers' misuse of corporate assets, and the strength of auditing and accounting standards in deciding about the level of information asymmetry becomes of increased interest, especially from cross-country perspective. The above-mentioned attributes of corporate governance allocate the power between the shareholders (stakeholders) and the managers of the entities doing business in a certain country. As a result, potential investors might be interested how their rights are protected and regulators might get the knowledge about how OECD corporate governance principles are applied into local environment characterized by various legal, regulatory and institutional features.

The aim of the paper is to reveal the specific corporate governance patterns depicted by European countries and to identify whether these patterns are relatively homogenous among groups of countries, or on the contrary there is evidence of increased dissimilarity. The purpose

Received by the editors June 5, 2021. Accepted by the editors June 21, 2021.

Keywords: corporate governance, agency conflict, cluster analysis, European countries.

JEL Classification: G30, M41, M42.

Iustina Alina Boitan* (Corresponding Author), $\mathrm{PhD}$, Associate Professor, Department of Money and Banking, Bucharest University of Economic Studies, Romania. E-mail: iustina.boitan@fin.ase.ro.

Ewa Wanda Maruszewska, PhD, Associate Professor, Department of Business Informatics and International Accounting, University of Economics in Katowice, Poland. E-mail: ewa.maruszewska@ue.katowice.pl.

This paper is in final form and no version of it will be submitted for publication elsewhere. 
of the study is to compare European Union countries (according to EU's 2019 membership) from the standpoint of the corporate governance attributes, which are measured by three indices encompassed into the Global Competitiveness Report (2019). We also add Norway in the sample as many previous analyses show this country is a leader in corporate governance (Mishra et al., 2002; Sinani et al., 2010; Knudsen and Langseth, 2020). Some of the countries included in the cluster analysis are also members of the OECD, an international authority who published the G20/OECD Principles of Corporate Governance (2015), so the clustering may help understand the similarities and differences between countries, according to their various memberships.

The novelty of our approach, compared with existing studies, relies in the focus on main corporate governance attributes that are primarily monitored by stakeholders, such as: the level of shareholders' rights, shareholders' protection against mismanagement practices, the strength of auditing and accounting standards and the incidence of corruption. Our findings complement the informational content provided by clusters previously identified in the literature e.g., based on the legal regime (code vs. common law) or soft/hard level of codes of corporate governance. However, this strand of literature is currently underdeveloped. Thus, we argue that in-depth analysis of other factors influencing corporate governance application level is needed, in order to gain a comprehensive view on the corporate governance environment within a given country.

The paper is organized as follows. Section 1 provides an overview of the theoretical background of agency conflict and its relation to corporate governance. It presents the broad framework of corporate governance research, their theoretical foundations as well as past studies using cluster analysis in the corporate governance field. Section 2 describes data selection and other methodological issues together with results of cluster analysis. Finally, concluding discussion summarizes the findings of the study.

\section{Country-level and firm-Level factors of Corporate governance - Past RESEARCH}

2.1. Broad framework of corporate governance. The importance of corporate governance for long-term economic welfare is emphasized in the literature especially since the last financial crisis as it helps to build the environment of trust, transparency and accountability (OECD, 2015). Institutional actors ensuring that corporate governance serves its purposes are shareholders (mainly capital providers defining the claims over the value creation of the entity) but also managers who are chief players in the value creation of the entity (Atm and Nisar, 2019). This view pinpoints that corporate governance is linked to detachment of ownership from management that is an important characteristic of modern entities.

Different characteristics of corporate governance also indicate two layers introduced by Gillan (2006): internal and external sets of corporate governance mechanisms serving for the value creation of the entity as well as for the distribution of its value to the stakeholders of the entity. Internal control mechanism consists of management (serving as an agent to the shareholders) and the board of directors who supervise the management. Besides the management and the board of directors, key components of internal governance are the capital structure, the bylaw and chartered provisions, and the internal control systems. Externally imposed control mechanisms are derived from shareholders (capital providers) as well as other stakeholders not only encompassing employees, customers and suppliers, but also law, community or the market in which the business operates. Thus, the key components of external governance are: (i) law and regulation, (ii) market 1 (capital market, market for corporate control, labor market, product market), (iii) market 2 (providers of information required by capital market 1 i.e., market analysts, credit analysts), (iv) market 3 (accounting, financial and legal services from outside parties external to the entity), and (v) private sources of external oversight (media and external lawsuits). 
On the one hand, encompassing the management into the corporate governance indicates the human element that can affect how regulation is applied in practice. On the other hand, inclusion of the community in which the entity operates (e.g., legal regulations, market characteristics etc.) shows the broad perspective of the corporate governance mechanism. Additionally, on may notice that some above-mentioned elements are not directly influencing corporate governance structures, but still, they may indirectly affect the application of corporate governance principles or may force managers to take account of the interests of different stakeholders. This is the reason why in a corporate governance literature one can find evaluation of two distinct models: shareholder model and stakeholder model giving priority to stakeholder model in respect to the corporate social responsibility idea that represents broader social expectations for nowadays organizations (Atm and Nisar, 2019; Desender et al., 2019). This shows that corporate embezzlement, misapplication of managerial authority should be seen in a broader context than only from the point of view of shareholders and wealth maximizing of their economic resources allocated in the entity. It indicates that at the heart of the corporate governance lies the fundamental purpose of the business entities and the strength of the conflicting interests that affect the outcomes of business operations (Jensen, 2001).

2.2. Theories incorporated into corporate governance research. As corporate governance is built upon the conflicting interests of many stakeholders, including management incentives not to act in accordance with the shareholders' goal, the agency theory is the dominant theoretical perspective (Cuomo et al., 2016; Schiehll and Martins, 2016) of corporate governance research. Agency theory is used to investigate the role of institutional actors and the codes of corporate governance (their content and development). These firm-level studies have also tried to explain compliance and non-compliance to the national codes of corporate governance and/or to codes issued by transnational institutions (Cuomo et al., 2016). Agency theory is also used on the country-level studies with macro-level features that influence corporate governance practices. Understanding the reasons for compliance and non-compliance as well as quality of explanations of deviations from the codes led researchers to studies indicating that in weak country-level corporate governance environment firms tend to improve firm-level governance in order to reassure the investors (Schiehll and Martins, 2016).

The above-described findings are in contrast to studies incorporating institutional theory that point to external corporate governance mechanisms as determinants of firm-level (internal) corporate governance practices (Schiehll and Martins, 2016). From this perspective, corporate governance - like other organizational forms - is the product of specific institutional environment (Colli and Colpan, 2016). Thus, the past research concentrates on searching for specific institutional changes that will allow corporate governance to flourish, especially when it comes to emerging markets.

Stakeholders' involvement in business operations, long-term contract based on the relationship between stakeholders and the corporation, confidence and business integrity are the main characteristics of stakeholder theory (Freeman, 1999) that is also foundation of corporate governance research. According to the broad framework of corporate governance described above, the stakeholder theory is inherently linked with the agency conflict not only between manager and the owner, but also between other parties representing different stakeholders of the entity.

2.3. Measuring corporate governance. Dey (2008) in her research - investigating whether corporate governance is associated with the level of agency conflict in firms - used seven factors that represented different dimensions of corporate governance. Her research was based on Larcker, Richardson, and Tuna (2007) who also developed indices of various dimensions of corporate governance using a large number of individual governance indicators. Two out of seven factors included variables related to the composition and functioning of the board, while the executive compensation was the third principal factor. The fourth principal factor was meant to capture the equity-based compensation provided to directors. The fifth factor described the independence of auditor, while the sixth the composition and functioning of the 
audit committee of the board of directors. The last, seventh factor was aimed at capturing the board's control over the financial reporting quality.

Williams and Segui-Mas (2010) conducted a cluster analysis by using 38 criteria from the economic freedom of the world index developed by the Fraser Institute. Among the variables included in the analysis both the firm-level as well as country-level were included. There were economic regulators, accounting standards, legal system, corruption, stakeholder management, and corporate governance codes. As a result of the four clusters obtained, they argue that each cluster conforms to the standards of the European Union on the surface, but at the same time their compliance is altered to some degree according to technical, cultural, and political processes as well as individual historical context. Their findings neither support the categorization between code and common law countries nor the classification of hard/soft corporate governance codes states.

Cicon et al. (2021) used legal regime for their clustering based on country-level variables. They categorized 23 European Union countries among common law regime, German civil, French civil, and global governance practices regime. Their findings are not totally consistent with the historical legal regime classification used in the past literature. Their two new groupings are: global governance practices (including inter alia Finland, the Czech Republic, Greece, Hungary, Poland, and Romania) and Baltic civil law with Estonia and Latvia as representatives. They conclude that any convergence between national corporate governance codes is more likely to occur on the basis of "best practices" than convergence to a common law.

Beekes et al (2016) use 24 underlying firm-level governance characteristics including the assessment of the board of directors and its committee, directors' stock ownership and compensation and others. Opposed to the above, Schiehll and Martins (2016) in their literature review present four country-level factors used by other authors to explain firm-level governance mechanism: capital structure, board of directors, financial information, and governance quality.

The above literature review shows that corporate governance has multiple dimensions. Most of the researchers focused on the individual (firm-level) features of entities describing individual governance mechanism mainly using selected variables from those introduced by Gillan (2006). Along with this line, we ask a question whether using data derived from the Global Competitiveness Report (2019) will generate clusters similar to those described in the past literature and built on the firm-level or country-level features. We stress that the issue is relevant because new clustering broadens the knowledge about the determinants affecting corporate governance practices in the presence of inconclusive previous research.

\section{Exploratory assessment of CROSS-COUNTRY FEATURES}

3.1. Data selection. Our research approach gravitates around the issue of corporate governance in European Union countries, as a catalyst factor for investors' confidence in a country's corporate governance model and the sound and sustainable development of an economy. To account for the degree of shareholders' rights and protection against mismanagement, as well as for the relevance and compliance with the accounting and reporting standards, we relied on a series of indices computed by the World Economic Forum, under the aegis of the Global Competitiveness Index. These indices represent the World Economic Forum's (2017) latest development of new concepts and measurements in terms of a country's competitiveness. Moreover, all the indices that compose the Global Competitiveness Index are the result of empirical and theoretical research and have proven to act as leading factors for the improvement of productivity, which is the main determinant of long-term economic growth and prosperity.

The four indices considered for our empirical analysis are represented by:

a) shareholder governance - measures shareholders' rights in a country's corporate governance framework;

b) conflict of interest regulation - measures the protection of shareholders against directors' misuse of corporate assets for personal gain; 
c) strength of auditing and accounting standards - measures how strong are financial auditing and reporting standards in a given country;

d) incidence of corruption - measures the perception of corruption in the public sector

Their scores are computed annually and range from 0 to 100 which signals the best performance. For the purpose of our study we included in the analysis only the most recent available data (related to 2019 year-end), to gain a preview on countries' positioning and resemblance in terms of key corporate governance indicators. Preliminary information on data features can be obtained from the computation of primary descriptive statistics (table 1).

\begin{tabular}{|l|c|c|c|c|c|c|c|c|c|}
\hline \multicolumn{9}{|c|}{ Table 1. Key descriptive statistics } \\
\hline Variable & No. of obs. & Range & Minimum & Maximum & Std. Dev. & \multicolumn{2}{|c|}{ Skewness } & \multicolumn{2}{c|}{ Kurtosis } \\
\hline & Statistic & Statistic & Statistic & Statistic & Statistic & Statistic & Std. Error & Statistic & Std. Error \\
\hline $\begin{array}{l}\text { Shareholder } \\
\text { governance }\end{array}$ & 29 & 36,00 & 47,00 & 83,00 & 8,36 & $-0,04$ & 0,43 & $-0,15$ & 0,85 \\
\hline $\begin{array}{l}\text { Conflict } \\
\text { of interest } \\
\text { regulation }\end{array}$ & 29 & 47,00 & 40,00 & 87,00 & 9,97 & 0,69 & 0,43 & 1,41 & 0,85 \\
\hline $\begin{array}{l}\text { Strength of } \\
\text { auditing and } \\
\text { accounting } \\
\text { standards }\end{array}$ & 29 & 45,60 & 46,60 & 92,20 & 11,28 & $-0,33$ & 0,43 & $-0,14$ & 0,85 \\
\hline $\begin{array}{l}\text { Incidence of } \\
\text { corruption }\end{array}$ & 29 & 46,00 & 42,00 & 88,00 & 14,34 & 0,03 & 0,43 & $-1,39$ & 0,85 \\
\hline \multicolumn{7}{|c|}{ Source: authors, based on SPSS software computation. } \\
\hline
\end{tabular}

The minimum score in the entire sample is recorded by the conflict of interest regulation (40), while the maximum score belongs to the strength of auditing and accounting standards $(92,2)$.

\begin{tabular}{|c|c|c|c|c|c|}
\hline \multicolumn{6}{|c|}{ Table 2. Correlation matrix } \\
\hline & & Shareholder & Conflict of & Strength of auditing & Incidence \\
\hline & & governance & interest regulation & and accounting standards & of corruption \\
\hline \multirow{2}{*}{$\begin{array}{l}\text { Shareholder gover- } \\
\text { nance }\end{array}$} & Pearson Correlation & 1 & 0,114 & $-0,069$ & $-0,005$ \\
\hline & Sig. (2-tailed) & & 0,557 & 0,721 & 0,978 \\
\hline \multirow{2}{*}{$\begin{array}{l}\text { Conflict of interest } \\
\text { regulation }\end{array}$} & Pearson Correlation & 0,114 & 1 & 0,010 & 0,242 \\
\hline & Sig. (2-tailed) & 0,557 & & 0,961 & 0,206 \\
\hline \multirow{2}{*}{$\begin{array}{l}\text { Strength of auditing } \\
\text { and accounting stan- } \\
\text { dards }\end{array}$} & Pearson Correlation & $-0,069$ & 0,010 & 1 & $.756^{* *}$ \\
\hline & Sig. (2-tailed) & 0,721 & 0,961 & & 0,000 \\
\hline \multirow{2}{*}{$\begin{array}{l}\text { Incidence of corrup- } \\
\text { tion }\end{array}$} & Pearson Correlation & $-0,005$ & 0,242 & $.756^{* *}$ & 1 \\
\hline & Sig. (2-tailed) & 0,978 & 0,206 & 0,000 & \\
\hline $\begin{array}{l}\text { **. Correlation is sig- } \\
\text { nificant at the } 0.01 \\
\text { level ( } 2 \text {-tailed). }\end{array}$ & & & & & \\
\hline
\end{tabular}

Related to the difference between the maximum and the minimum scores, the lowest range is attributed to shareholder governance, signaling the presence of less extreme values. Standard deviation indicates the spread of data around sample's average; higher values of this statistic 
are associated with increased heterogeneity in data and presence of extreme values. The incidence of corruption exhibits the highest data variability, followed by the strength of auditing and accounting standards. Therefore, these variables are expected to influence the most the classification of countries into resembling groups. Skewness and kurtosis statistics provide information on the shape and symmetry of the distribution function. The most asymmetry is shown by the conflict of interest regulation, being biased towards higher values. All variables have a platikurtotic shape, lower than the normally distributed function.

The correlation analysis illustrated in table 2 identifies the presence of a highly statistically significant correlation between the strength of auditing and accounting standards and the incidence of corruption variables for a cut-off probability of $1 \%$. Thus, the following empirical investigation will rely on only 3 out of 4 variables, by removing the incidence of corruption from our sample.

Additional information on variables' features is provided by the computation of the frequency of data occurrence for each variable in the sample.

Figure 1. Frequencies in data
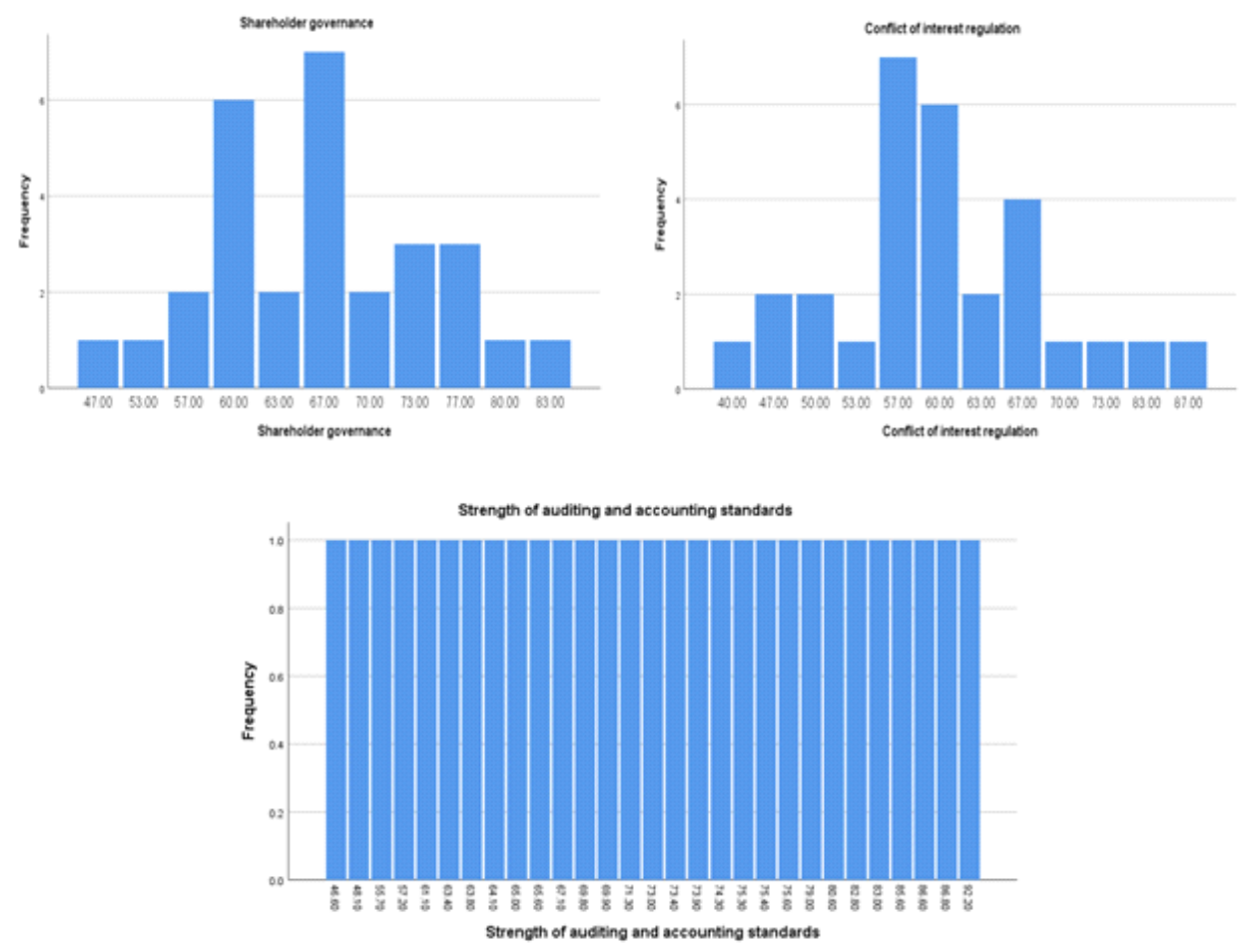

European countries seem to exhibit most similarities in terms of shareholder governance, as the same value is recorded by several countries (up to 7), followed by the conflict of interest regulation. In terms of the strength of auditing and accounting standards, each country records a unique value, suggesting that this is a persistent issue of heterogeneity among countries.

By reconciling the informational content brought by the primary descriptive statistics and the frequencies related to input variables, it can be concluded that the variability in clusters' composition is mainly due to changes in the level of the strength of auditing and reporting standards.

3.2. Methodological issues. The most suitable method for conducting our exploratory analysis is based on a statistical series of algorithms called cluster or taxonomy analysis. The core advantage of this method relies in the identification of existing patterns in the initial dataset and the further classification of European countries into more homogenous, resembling groups. 
A distinctive feature of clustering algorithms is connected with their ability of recognizing latent existing patterns into large amounts of data, being subordinated to the principle of "letting the data speak for themselves" (Farnè and Vouldis, 2017).

It is employed a hierarchical agglomerative approach, that follows a bottom-up aggregation of countries in the process of classification and cluster identification. Therefore, each of the 29 European countries first enters the analysis as an individual cluster, and then the linking algorithm is successively merging countries into pairs of similar clusters. This method implies passing through two successive computational steps, namely: (i) computing the proximity or distance between individual countries, and (ii) computing the proximity between groups of countries based on a pre-established linkage rule.

In the first step we rely on the squared Euclidean distance to measure the proximity (similarity) between each pair of observations belonging to a particular country, with the formula: squared Euclidian distance $=\sum_{i=1}^{n}\left(p_{i}-q_{i}\right)^{2}$, where $p_{i}$ and $q_{i}(i=1,2, . ., n)$ are two points in the Euclidean $n$-space.

In the second step it is employed the Ward linkage method in order to compute the distance between clusters and identify those clusters that may merge together. Economic literature advocates for this linkage method as a robust algorithm, being based on minimizing withincluster contribution to the overall variance of a given variable, or alternatively on maximizing the between-cluster contribution (Irac and Lopez, 2015). In a complementary manner, Murtagh and Legendre (2014) argue that Ward linkage method is the only agglomerative clustering method that makes use of the sum-of-squares criterion and generates groups that minimize within-group dispersion at each binary fusion.

The general Ward formula for merging two clusters denoted A and B is $\frac{n A \times n B}{n A+n B}(c A-c B)^{2}$, where $n A$ and $n B$ represent the number of countries included in clusters $A$ and $B$, and $c A$ and $c B$ are the centers of the two clusters.

The main output of this analysis consists of a clustering solution represented by a graphical hierarchical tree (also called dendrogram) which illustrates the order clusters have emerged and their composition. Each cluster consists of countries exhibiting specific, but similar features (Farnè and Vouldis, 2017).

The three uncorrelated indicators which are proxy for a country's corporate governance environment have different means and standard deviations, thus the clustering methodology requires smoothing the presence of extreme values. Consequently, each input variable is standardized by applying the z-score method: the mean of the overall sample is subtracted from each individual value, and then it is divided by the standard deviation of the overall sample for a given variable. Further, standardized values are used for conducting the cluster analysis.

3.3. Results and interpretation. To the best of our knowledge, there are a wide number of studies that choose the smallest distance range (0-5) for interpreting the clustering solution. It is also our case, as we intend to conduct a granular analysis meant to preserve the intrinsic features of European countries, to uncover which are the closest peers (included in the membership of the same group) and whether there is presence of heterogeneity among countries given the three input variables employed. The clustering solution best describing the intrinsic informational content of the three corporate governance variables belongs to a distance interval of $0-5$. The hierarchical tree presented in Figure 2 shows the cluster each country had been assigned and reveals the presence of seven groups. Baseline features of countries included in each cluster, from the standpoint of the corporate governance patterns, are detailed in Table 3.

A first finding is related to the high number of groups generated by the clustering algorithm, suggesting increased cross-country heterogeneity in terms of corporate governance features. A second finding emerges when comparing the characteristics of the various clusters, summarized in table 3: the best performing countries are those included in cluster no. 7, followed by cluster no. 6 . The remaining clusters exhibit mixed performance among the three governance variables. For instance, cluster no. 4 registers striking features, such as the worst performance 
in terms of shareholders' rights in corporate governance but the best performance in terms of compliance with and strength of auditing and reporting standards. In a similar fashion, cluster no. 5 gathers countries facing the weakest protection of shareholders against directors' misuse of corporate assets for personal gain, but good performance in terms of the strength of auditing and reporting standards.

\begin{tabular}{|c|c|c|}
\hline \multicolumn{3}{|c|}{ Table 3. Clusters' characteristics in 2019} \\
\hline $\begin{array}{l}\text { List of } \\
\text { iden- } \\
\text { tified } \\
\text { clusters }\end{array}$ & Cluster membership & Cluster characteristics \\
\hline Cluster 1 & $\begin{array}{l}\text { Italy, Portugal, Poland, } \\
\text { Romania, Czech Rep., Es- } \\
\text { tonia }\end{array}$ & $\begin{array}{l}\text { below-average level for shareholder performance and strength of auditing and } \\
\text { reporting standards, close to average values for conflict of interest regulation }\end{array}$ \\
\hline Cluster 2 & $\begin{array}{l}\text { Bulgaria, Cyprus, Slove- } \\
\text { nia, Latvia }\end{array}$ & $\begin{array}{l}\text { above-average values for shareholder performance and conflict of interest reg- } \\
\text { ulation, below-average values for the strength of auditing and reporting stan- } \\
\text { dards }\end{array}$ \\
\hline Cluster 3 & Croatia, Greece & $\begin{array}{l}\text { above-average values for shareholder performance, below-average values for } \\
\text { conflict of interest regulation, the smallest values in the sample for the } \\
\text { strength of auditing and reporting standards }\end{array}$ \\
\hline Cluster 4 & $\begin{array}{l}\text { Belgium, Finland, Luxem- } \\
\text { bourg }\end{array}$ & $\begin{array}{l}\text { the smallest values in the sample for shareholder performance, close to aver- } \\
\text { age values for conflict of interest regulation, the highest values in the sample } \\
\text { for the strength of auditing and reporting standards }\end{array}$ \\
\hline Cluster 5 & $\begin{array}{l}\text { Hungary, Slovakia, Ger- } \\
\text { many, Malta, Netherlands }\end{array}$ & $\begin{array}{l}\text { below-average values for shareholder performance, the smallest values in the } \\
\text { sample for conflict of interest regulation, high values for the strength of au- } \\
\text { diting and reporting standards }\end{array}$ \\
\hline Cluster 6 & Ireland, UK & $\begin{array}{l}\text { close to average values for shareholder performance, the highest values in } \\
\text { the sample for conflict of interest regulation, above-average values for the } \\
\text { strength of auditing and reporting standards }\end{array}$ \\
\hline Cluster 7 & $\begin{array}{l}\text { Austria, Norway, France, } \\
\text { Spain, Lithuania, Den- } \\
\text { mark, Sweden }\end{array}$ & $\begin{array}{l}\text { the highest values in the sample for shareholder performance, above-average } \\
\text { values for conflict of interest regulation and the strength of auditing and } \\
\text { reporting standards }\end{array}$ \\
\hline \multicolumn{3}{|c|}{ Note: authors' analysis, based on dendrogram clustering and } \\
\hline & escript & statistics (sample's average, maximum and minimum) \\
\hline
\end{tabular}

As a robustness check, we conducted again the hierarchical cluster analysis, by replacing the Ward linkage method with the average linkage (between groups) one. The new clustering solution resembles the initial one; therefore we can conclude that the countries' classification is stable and the conclusions hold, irrespective the merging rule used for gathering countries into similar groups.

An additional robustness check, meant also to reveal the time persistence of the previously identified country patterns, consists in performing the cluster analysis for a different timeframe. It has been considered the years 2017 and 2018, to gain an insight on the developments in the corporate governance features in successive periods of time. Table 4 summarizes the new classification of countries in resembling groups, based on the hierarchical trees.

The new clustering solutions reveal that the classification of countries into homogenous groups is almost unchanged between 2018 and 2019, while some slight differences appear between 2017 and the next two years. The picture in 2017 is characterized by the presence of 5 groups, while the subsequent two years witness an increase of countries' dissimilarity which is proven by the identification of a bigger number of groups. The number of clusters generated by the algorithm is directly determined by the resemblance pattern across countries. Therefore, the three-year path recorded by each corporate governance indicator and aggregated through the clustering algorithms is signaling a diverging trend across European countries. 
Figure 2. Cluster analysis hierarchical tree (dendrogram) for 2019 data

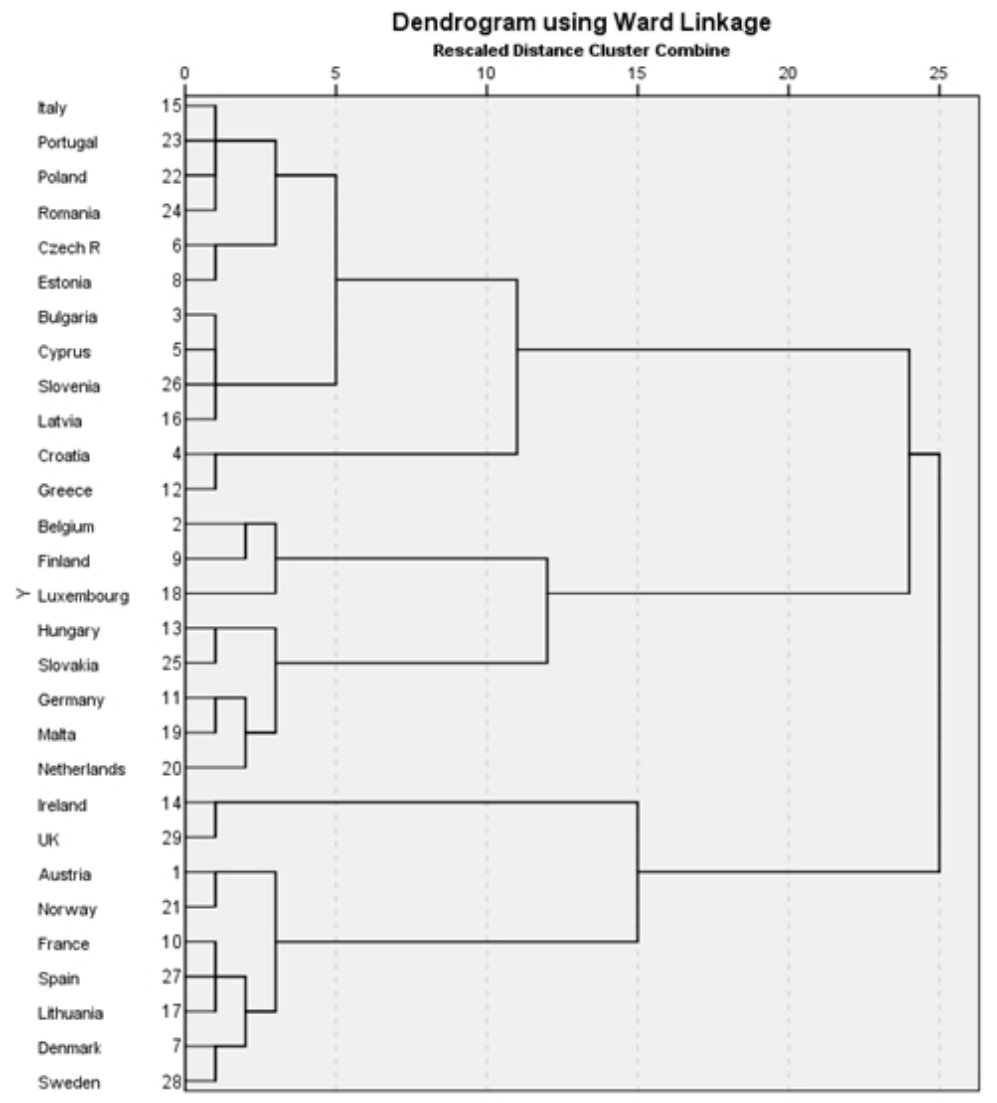

Source: authors, based on SPSS software computations

There is also the presence of several stable groups, irrespective the year considered. The countries always included in the membership of the same group are: i) Denmark, Sweden and Norway; ii) Finland and Belgium; iii) Croatia and Greece; iv) Portugal and Poland; v) Romania and Italy; vi) Bulgaria and Slovenia; vii) Ireland and UK; viii) Germany, Malta and Netherlands; ix) Austria and France. Thus, the domestic features of the corporate governance environment are persistently evolving in the same manner for each of these groups. For instance, the group composed by Denmark, Sweden and Norway is always exhibiting the best performance in each of the three-year timeframe.

\section{Discussion AND CONClusions}

It is interesting that only in case of two clusters ( 1 and 7 as presented in table 3 ) both indicators: shareholder performance and auditing and reporting standards show the same high (cluster 7) or low (cluster 1) levels. In cluster 1, the below-average level of shareholders goes together with a below-average level of auditing and reporting standards indicator, hence indicating a weak external control mechanism in a form of law and regulation referring to providers of information to the capital market, i.e. managers, accountants and auditors who are asked to guarantee a high quality financial information about the performance of the entity. In case of cluster 7, externally imposed control mechanism is successfully in force ensuring that the corporate governance serves its purposes. On the contrary, in case of clusters $2,3,4,5$, and 6 the deficiency of one external control mechanism is leveled by the strength of another. 


\begin{tabular}{|c|c|c|c|c|}
\hline \multicolumn{5}{|c|}{ Table 4. Clusters' features in 2017 and 2018} \\
\hline \multirow[t]{2}{*}{ List of identified clusters } & \multicolumn{2}{|c|}{ Cluster membership } & \multicolumn{2}{|c|}{ Cluster characteristics } \\
\hline & 2017 & 2018 & 2017 & 2018 \\
\hline Cluster no. 1 & $\begin{array}{l}\text { Estonia, } \\
\text { many, } \\
\text { Rep., } \\
\text { Malta, } \\
\text { France, } \\
\text { Nethium, } \\
\text { Finland, }\end{array}$ & $\begin{array}{l}\text { Latvia, } \text { Lithua- } \\
\text { nia, Cyprus, } \\
\text { Poland, Romania, } \\
\text { Italy, Portugal }\end{array}$ & $\begin{array}{l}\text { some of the largest values in } \\
\text { the sample for shareholder } \\
\text { governance, close to average } \\
\text { values for conflict of inter- } \\
\text { est, the highest values in the } \\
\text { sample for strength of audit- } \\
\text { ing and reporting standards }\end{array}$ & $\begin{array}{l}\text { above average values for } \\
\text { shareholder governance, } \\
\text { close to average for conflict } \\
\text { of interest, below-average } \\
\text { strength of auditing and } \\
\text { reporting standards }\end{array}$ \\
\hline Cluster no. 2 & $\begin{array}{l}\text { Luxembourg, Slo- } \\
\text { vakia }\end{array}$ & $\begin{array}{l}\text { Bulgaria, Spain, } \\
\text { Slovenia }\end{array}$ & $\begin{array}{l}\text { close to average values for } \\
\text { shareholder gov., the small- } \\
\text { est values for conflict fo in- } \\
\text { terest, above-average values } \\
\text { for strength of auditing }\end{array}$ & $\begin{array}{l}\text { above average values for } \\
\text { shareholder governance and } \\
\text { conflict of interest, below- } \\
\text { average for strength of au- } \\
\text { diting standards }\end{array}$ \\
\hline Cluster no. 3 & $\begin{array}{l}\text { Norway, } \\
\text { Denmark, } \\
\text { Sweden, Ireland }\end{array}$ & Croatia, Greece & $\begin{array}{l}\text { the highest values in the } \\
\text { sample for shareholder gov. } \\
\text { and conflict of interest, } \\
\text { some of the highest values } \\
\text { for strength of auditing }\end{array}$ & $\begin{array}{l}\text { above average values for } \\
\text { shareholder gov., below- } \\
\text { average for conflict of } \\
\text { interest, the lowest values in } \\
\text { the sample for the strength } \\
\text { of auditing }\end{array}$ \\
\hline Cluster no. 4 & $\begin{array}{l}\text { Hungary, } \quad \text { Por- } \\
\text { tugal, } \\
\text { Spain, } \\
\text { Lithuania }\end{array}$ & Ireland, UK & $\begin{array}{l}\text { below-average values for } \\
\text { shareholder gov., close } \\
\text { to average for conflict of } \\
\text { interest, below average } \\
\text { values for strength of } \\
\text { auditing }\end{array}$ & $\begin{array}{l}\text { close to average values for } \\
\text { shareholder gov., the high- } \\
\text { est values in the sam- } \\
\text { ple for conflict of interest, } \\
\text { slightly above-average val- } \\
\text { ues for strength of audit }\end{array}$ \\
\hline Cluster no. 5 & $\begin{array}{l}\text { Bulgaria, Slove- } \\
\text { nia, Croatia, } \\
\text { Cyprus, Greece, } \\
\text { Italy, Romania }\end{array}$ & $\begin{array}{l}\text { Denmark, Swe- } \\
\text { den, Austria, } \\
\text { France, Norway }\end{array}$ & $\begin{array}{l}\text { the lowest values in the sam- } \\
\text { ple for shareholder gov. and } \\
\text { strength of audit, above- } \\
\text { average values for conflict of } \\
\text { interest }\end{array}$ & $\begin{array}{l}\text { the highest values for share- } \\
\text { holder governance, above- } \\
\text { average values for conflict of } \\
\text { interest and strength of au- } \\
\text { dit }\end{array}$ \\
\hline Cluster no. 6 & - & $\begin{array}{l}\text { Finland, Luxem- } \\
\text { bourg, Belgium }\end{array}$ & - & $\begin{array}{l}\text { some of the smallest val- } \\
\text { ues in the sample for share- } \\
\text { holder gov., above-average } \\
\text { values for conflict of inter- } \\
\text { est, the highest values for } \\
\text { strength of auditing }\end{array}$ \\
\hline Cluster no. 7 & - & $\begin{array}{l}\text { Germany, Malta, } \\
\text { Netherlands, } \\
\text { Czech Rep., } \\
\text { Estonia, Slovakia, } \\
\text { Hungary }\end{array}$ & - & $\begin{array}{l}\text { below-average values for } \\
\text { shareholder gov., the small- } \\
\text { est values in the sample } \\
\text { for conflict of interest, } \\
\text { above-average values for } \\
\text { strength of audit }\end{array}$ \\
\hline & th & analysis, based o & ndrogram clustering and & \\
\hline
\end{tabular}

Further, clusters 2 and 3 composed by Bulgaria, Cyprus, Slovenia, Latvia, Croatia and Greece are characterized by above-average values for shareholders performance and below-average auditing and reporting standards. These south European countries (except for Latvia) are characterized by high shareholders' rights protection specific to common law countries, although their 
audit and reporting standards indicators are below-average suggesting a shareholder model of corporate governance similar to that described in the literature (Atm and Nisar, 2019; Desender et al., 2019). This finding is compelling as it suggests that countries included in clusters 2 and 3 use a mix of features from common and code (civil) law systems for corporate governance regulations.

As regards the countries included in clusters 4, 5, and 6 (Belgium, Finland, Luxembourg, Hungary, Slovakia, Germany, Malta, Netherlands, Ireland and UK) it can be observed that they all show above-average values for auditing and reporting standards indicator with belowaverage (or close to average in case of cluster 6) values for shareholder performance indicator. This suggests that externally imposed control mechanisms are in force mainly in the field of providers of financial information and the corporate governance legal framework can be further developed in order to facilitate the exercise of shareholder's rights.

The above-mentioned findings obtained complement the existing literature, and suggest that classification to code and common law countries as well as to hard and soft corporate governance codes or other cross-national characteristics does not explain corporate governance practices in full (Siems, 2007; Sarkar, 2011). It also suggests that governance mechanisms may be mainly shaped by endogenous features of entities which is somehow in contrast to Dey (2008) findings supporting institutional theory.

In addition, our study is in accordance with the debates on different institutional environment effectiveness on the solving of agency conflict with corporate governance mechanism (Cuomo et al., 2016; Schiehll and Martins, 2016), as the countries included into clusters 2, 6, and 7 show above-average values for the conflict of interest indicator. Ireland and UK (cluster 6) exhibit the highest values suggesting that the prevention and elimination of those situations that may trigger a board of directors' conflict of interest is lowering the risk of making business decisions not in the best interest of the entire organization. It is interesting to note that the clustering revealed similarities in the scope of conflict of interest between Bulgaria, Cyprus, Slovenia, Latvia (cluster 2) and Austria, Norway, France, Spain, Lithuania, Denmark, and Sweden (cluster 7). This finding suggests that the countries gathered in cluster 2 have significantly developed their corporate governance environment in the past years. On the other hand, countries included in clusters 3 and 5 (Croatia, Greece, Hungary, Slovakia, Germany, Malta, and Netherlands) exhibit below-average values indicating the inherent risk of a conflict of interest when business decisions are influenced by a secondary interest, such as personal monetary or non-monetary focus. It is also worth noting that countries encompassed in cluster 1, with below-average shareholders protection and audit and reporting standards indicators, show average values only for conflict of interest. When comparing clustering as of 2019 with that obtained for 2017 and 2018, the findings indicate no improvement in the field. Although this particular indicator (out of the three indicators chosen for the clustering) records the highest values in comparison to the other two indicators (in case of cluster 1), it seems that the overall development of the corporate governance environment requires ongoing improvement. This is valid especially when legal external mechanism shows below-average level.

Additionally, as our findings indicate a state of volatility in the values of the three governance indicators, it is important to pinpoint the need for ongoing development of corporate governance regulations and continuous improvement as a response to the business environment changing conditions. This opinion should serve as a basic guideline for all the countries included into the clustering, including those showing the highest values in 2019. This is in line with the findings of Segui-Mas (2010) who argued that each country complies with the standards of the European Union on the surface, but at the same time countries' dissimilarities can be observed. Our study, grouping the European countries into 7 clusters both in 2018 and 2019 confirm this previous literature result.

Contrary to Cicon et al. (2021) who used legal regime as indices for the clustering, we did not find evidence of grouping the Baltic countries into a single cluster. Estonia and Latvia, the representatives for Cicon et al. (2021) grouping, are not included in the same clusters in our 
study. What is even more thought-provoking is that Estonia, Latvia, and Poland were classified into clusters 1 and 2, while Lithuania into cluster 7 representing the highest scores. Although our study did not replicate the clusters of Cicon et al. (2021), our findings are in line with their main conclusion that corporate governance seems to be built more on "best practices" than on the basis of legal regulations.

Summarizing, our findings are in line with Williams and Segui-Mas (2010) who argue that European Union countries adapt governance practices according to their technical, cultural, and political processes, lowering the standardization directives. Hence, our findings call for integrated perspective studies of external corporate governance mechanisms together with internal corporate governance factors, in order to investigate cross-country differences in corporate governance codes and practices. Also theoretical corporate governance literature indicates that differences between governance systems can enhance the development of more holistic approach to governance problems (Desender et al., 2019; Zattoni et al., 2020). That is why we call for preparation of comprehensive resolution of shareholders governance and strength of auditing and accounting standards by regulators from cluster 1 countries (according to 2019 classification), that is: Italy, the Czech Republic, Poland, Portugal, and Romania. This call is also valid to other countries with below average indices used in the cluster analysis.

The discussion of our findings reveals that countries placed in cluster 1 can develop their best practices of corporate governance in order to evolve with the level of shareholders governance and the strength of auditing and accounting using the experience of other countries that found particular institutional features enabling corporate governance to flourish (Colli and Colpan, 2016). On the other hand, past research pinpoints that regulators should take into account the interaction of developed legislature (e.g., corporate law) with other national institutions (Zattoni et al., 2020). This also might be a future path of research for each clusters coded in this study.

For countries in cluster 5 (Hungary, Slovakia, Germany, Malta, and Netherlands) it seems appropriate to use the findings of Renders and Gaeremynck (2012) who argue that when agency conflicts are severe (e.g., as a result of non-existence or poor quality of conflict of interest regulations), the cost of installing of good governance mechanisms are high, but once installed result in higher firm value. This is also valid for most of the countries that in 2017 or 2018 were included into groups characterized by below-average conflict of interest indicator.

The above-described results of our study should be interpreted within the research limitation. We conducted our study among European Union countries based on 2019 data derived from the World Economic Forum. A broader analysis encompassing more countries and in-depth analysis of other characteristics of external corporate governance mechanisms (as they will be developed and included as a pillar of country's competitiveness) implemented in selected countries can be a path for future research.

\section{REFERENCES}

[1] Atm Adnan, and Nisar Ahmet. 2019. "The transformation of the corporate governance model: a literature review". Copernican Journal of Finance and Accounting, no 8(3): 7-47. https://doi.org/10.12775/CJFA.2019.11.

[2] Beekes Wendy, Brown Philip, Zhan Wenwen, and Zhang Qiyu. 2012. "Corporate governance, companies' disclosure practices and market transparency: a cross country study". Journal of Business Finance and Accounting, no 43(3): 263-297. https://doi.org/10.1111/jbfa.12174.

[3] Cuomo Francesca, Mallin Christine, and Zattoni Alessandro. 2016. "Corporate governance codes: a review and research agenda". Corporate Governance: An International Review, no 24(3): 222-241. https://doi.org/10.1111/corg.12148.

[4] Desender A. Kurt, Lopez Puertas-Lamy Monica, Pattitoni Pierpaolo, and Petracci Barbara. 2019. "Corporate social responsibility and cost of financing - the importance of the international corporate governance system". Corporate Governance: International Review, no 28: 207-234. https://doi.org/10.1111/corg.12312.

[5] Dey Aiyesha. 2008. "Corporate governance and agency conflict". Journal of Accounting Research, no 46(5): 1143-1181. https://doi.org/10.1111/j.1475-679X.2008.00301.x. 
[6] Farnè Matteo., and Vouldis Angelo. 2017. "Business models of the banks in the euro area", ECB Working Paper series No 2070 / May 2017.

[7] Freeman R. Edward. 1999. "Response: Divergent stakeholder theory". Academy of Management Review, no 24(2): 233-236.

[8] Gillan L. Stuart. 2006. "Recent developments in corporate governance: an overview". Journal of Corporate Finance, no 12: 381-402. https://doi.org/10.1016/j.jcorpfin.2005.11.002.

[9] Irac, Delphine, and Lopez Jimmy. 2015. "Euro Area Structural Convergence? A Multi-criterion Cluster Analysis". International Economics, no. 143: 1 - 22. http://dx.doi.org/10.1016/j.inteco.2015.01.005.

[10] Jensen C. Michael. 2001. "Value maximization, stakeholder theory, and the corporate objective function". Journal of Applied Corporate Finance, no 14(3): 8 - 21. http://papers.ssrn.com/abstract=220671.

[11] Knudsen Gudmund, and Langseth Erik. 2020. "The corporate governance review: Norway", The Law Reviews, 24.03.2020. https://thelawreviews.co.uk/title/the-corporate-governance-review/norway.

[12] Larcker David, Richardson Scott, andTuna Irem. 2007. "Corporate governance, accounting outcomes and organizational performance". The Accounting Review, no 82: 963-1008. https://doi.org/10.2308/accr.2007.82.4.963.

[13] Linnenluecke Martina, Marrone Mauricio, and Singh Abhay. 2020. "Sixty years of accounting and finance: a bibliometric analysis of major research themes and contributions". Accounting and Finance, no 60: 32173251. https://doi.org/10.1111/acfi.12714.

[14] Mishra Chandra, Randoy Trond, and Jenssen Jan Inge. 2002. "The effect of founding family influence on firm value and corporate governance". Journal of International Financial Management and Accounting, no 12(3): 235-259. https://doi.org/10.1111/1467-646X.00073.

[15] Murtagh Fionn, and Legendre Pierre. 2014. "Ward's Hierarchical Agglomerative Clustering Method: Which Algorithms Implement Ward's Criterion?", Journal of Classification, no 31: 274-295, https://doi.org/10.1007/s00357-014-9161-z.

[16] OECD (2015), "G20/OECD Principles of Corporate Governance", OECD Publishing, Paris. https://doi.org/10.1787/9789264236882-en.

[17] Renders Annelies, and Gaeremynck Ann. 2012. "Corporate governance, principal-principal agency conflicts, and firm value in European listed companies". Corporate Governance: An International Review, no 20(2): 125-143. https://doi.org/10.111/j.1467-8683.2011.00900.x.

[18] Sarkar Prabirjit. 2011. "Common law vs. civil law: Which system provides more protection to shareholders and promotes financial development". SSRN Electronic Journal, no II(2): 143-161. http://dx.doi.org/10.2139/ssrn.1913624.

[19] Schiehll Eduardo, and Martins Henrique Castro. 2016. "Cross-national governance research: a systematic review and assessment". Corporate Governance: An International Review, no 24(3): 181-199. https://doi.org/10.1111/corg.12158.

[20] Siems, Mathias. 2007. "Shareholder protection around the world ("Leximetric II")". Working Paper No. 359. Centre for Business Research, University of Cambridge, https://core.ac.uk/download/pdf/7151365.pdf.

[21] Sinani Evis, Stafsudd Anna, Thomsen Steen, Edling Christofer and Randoy Trond. 2010. "Corporate governance in Scandinavia: comparing networks and formal institutions", European Management Review., no 5(1): 27-40. https://doi.org/10.1057/emr.2008.1.

[22] Williams Clark, and Segui-Mas Elies. 2010. "Corporate governance and business ethics in the European Union: a cluster analysis". Journal of Global Responsibility, no 1(1): 98-126. https://doi.org/10.1108/20412561011039735.

[23] World Economic Forum, 2017. "Global Competitiveness Report 2017", http://www3.weforum.org/ docs/GCR2017-2018/05FullReport/TheGlobalCompetitivenessReport2017\%E2\%80\%932018.pdf .

[24] World Economic Forum, 2019. "Global Competitiveness Report 2019", https://www.weforum.org/reports/global-competitiveness-report-2019.

[25] Zattoni Alessandro, Dedoulis Emmanouil, Leventis Stergios, and Hans van Ees. 2020. "Corporate governance and institutions - a review and research agenda". Corporate governance: An International Review, no 28: 465-487. https://doi.org/10.1111/corg.12347. 